\title{
UNDERSTANDING BLENDED LEARNING STRATEGY IN INCREASING STUDENTS MOTIVATION AFTER REOPENING SCHOOLS
}

\author{
Nuah PerdamentaTarigan ${ }^{1}$, Budi Sulistiyo Nugroho ${ }^{2}$, Lela Susanty ${ }^{3}$, Khasanah ${ }^{4}$, \\ Fety Surfaifel ${ }^{5}$ \\ ${ }^{1}$ Universitas UPH DRM Edu, Jakarta, Indonesia \\ ${ }^{2}$ Politeknik Energi dan Mineral Akamigas (PEM Akamigas), Indonesia \\ ${ }^{3}$ STBA YAPARI ABA Bandung, Indonesia \\ ${ }^{4}$ Universitas Siber Asia, Jakarta, Indonesia \\ ${ }^{5}$ Univeristas Flores, Indonesia \\ Email: nuahptarigan1@gmail.com,nbudi.nugroho@gmail.com, leilashanty7@gmail.com \\ khasanah.pase@gmail.com, fetysurfaifel@upi.edu
}

\begin{abstract}
This exploration is expected to search many insightful articles on mixed helping blended learning strategies to upgrade understudy learning results in complex and routine circumstances. To all the more likely comprehend and scholarly involvement in mixed learning, we accumulated information and data by doing a virtual information search on some notable distributions on educational issues and utilizing innovation to improve learning results. We utilized the expressions "distributions" to allude to information from ERIC, Google Books, Taylor\&France, Elsevier, and Sagepub. We directed a topto-bottom review utilizing an inside and out evaluation and coding framework to find the solutions utilizing a phenomenological technique. Subsequently, given the assessment of the principal discoveries, we can presume that a hybrid or blended learning system is a learning approach that consolidates a scope of instructive procedure techniques to help understudies accomplish more prominent degrees of accomplishment than traditional methodologies alone. A mixture and blended learning framework joins vis-à-vis guidance with PC helped training. It is expected that these outcomes would fill in as supporting writing for future examinations and applications.
\end{abstract}

Keywords: Blended learning, improving outcomes, Reopening School. Study Educational studies

\begin{abstract}
Abstrak
Eksplorasi ini diharapkan dapat mencari banyak artikel berwawasan tentang strategi pembelajaran campuran yang membantu meningkatkan basil belajar siswa dalam situasi yang kompleks dan rutin. Untuk lebih memahami dan terlibat secara ilmiah dalam pembelajaran campuran, kami mengumpulkan informasi dan data dengan melakukan pencarian informasi virtual pada beberapa distribusi penting tentang masalah pendidikan dan memanfaatkan inovasi untuk meningkatkean basil pembelajaran. Kami menggunakan istilah "distribusi" untuk merujuk pada informasi dari ERIC, Google Books, TaylorerFrance, Elsevier, dan Sagepub. Kami mengarabkan tinjanan atas-ke-bawah
\end{abstract}


menggunakan evaluasi luar dan dalam dan kerangka kerja pengkodean untuk menemukan solusi menggunakan teknik fenomenologis. Selanjutnya, mengingat penilaian penemuan-penemuan utama, kami dapat menganggap bahwa sistem pembelajaran bybrid atau campuran adalah pendekatan pembelajaran yang menggabungkan ruang lingkup teknik prosedur instruktif untuk membantu siswa mencapai tingkat prestasi yang lebih menonjol daripada metode tradisional saja. Kerangka kerja pembelajaran campuran dan campuran menggabungkan secara tatap muka dengan pelatiban yang dibantu PC. Diharapkan bahwa hasil ini akan mengisi sebagai tulisan pendukung untuk ujian dan aplikasi di masa depan.

Kata Kunci: Blended learning, peningkeatan hasil, Reopening School. Studi Studi Pendidikan.

\section{INTRODUCTION}

Understanding various learning strategies is essential for every educator, curriculum designer, school leader, and educational researcher to motivate students' enthusiasm for learning in taking lessons that are indeed very challenging and demanding in this competitive era. ${ }^{1}$ One of the strategies that are now very intensively discussed by the parties in the educational environment is the blending learning strategy. This learning strategy has proven to increase students' enthusiasm during the pandemic and hopefully after reopening schools. ${ }^{2}$ Regardless of academic program and activity, an educational institution aims to help students develop and improve learning outcomes a multidimensional set of skills, ideas, knowledge, methods, regulations, and cycles that will enable students to navigate the learning path with confidence bearing and understanding. Therefore, schools and teacher councils need to promote self-mastery skills and a positive attitude when taking tests and achieving learning goals. $^{3}$

Next year, schools need to organize student learning if the pandemic begins to subside with limited school conditions and various strategies. Last year, schools were closed in response to Covid-19, introducing students to multiple devices and diverse learning cycles. At times, teachers feel as if they have sacrificed depth for the sake of student breadth. So, in 2021, schools want to be a little humbler in serving each learning model and approach, providing enough opportunities for the appearance of student learning outcomes, discussion methods, and regular reflection, which sometimes schools lose strategies that until last year limited to adapting all student learning ways. ${ }^{4}$ As teachers, the goal is to support students in

${ }^{1}$ Curtis J. Bonk dan Charles R. Graham, The handbook of blended learning: Global perspectives, local designs (John Wiley \& Sons, 2012). Aslan Aslan dan Suhari Suhari, "Sejarah Kurikulum Pendidikan Islam di Brunei Darussalam," Jurnal Iqra': Kajian Ilmu Pendidikan 4, no. 1 (2019): 113-27. Aslan Aslan, "MAKNA KURIKULUM TERHADAP TEORI TENTANG BELAJAR PADA PERUBAHAN PERILAKU ANAK DIDIK," Cross-Border: Jurnal Kajian Perbatasan Antarnegara, Diplomasi Dan Hubungan Internasional 1, no. 2 (2018): 56-65. Aslan Aslan, HIDDEN CURRICULUM (Pena Indis, 2019).

2 S. Fitri dan C. L. Zahari, "The implementation of blended learning to improve understanding of mathematics," dalam Journal of Physics: Conference Series, vol. 1188 (IOP Publishing, 2019), 012109. Sardjana Orba Manullang, Mardani Mardani, dan Aslan Aslan, "The Effectiveness of Al-Quran Memorization Methods for Millennials Santri During Covid-19 in Indonesia," Naz̧hruna: Jurnal Pendidikan Islam 4, no. 2 (12 Juni 2021): 195-207, https://doi.org/10.31538/nzh.v4i2.1334.

3 Azmahani A. Aziz, Khairiyah M. Yusof, dan Jamaludin M. Yatim, "Evaluation on the effectiveness of learning outcomes from students' perspectives," Procedia-Social and Behavioral Sciences 56 (2012): 22-30.

${ }^{4}$ Johannes Cronje, “Towards a new definition of blended learning," Electronic journal of e-Learning 18, no. 2 (2020): pp114-121. Purniadi Putra dkk., "The Students Learning from Home Experiences during Covid-19 School Closures Policy In Indonesia," Jurnal Iqra': Kajian Ilmu Pendidikan 5, no. 2 (5 September 2020): 30-42, https://doi.org/10.25217/ji.v5i2.1019. Aslan Aslan dkk., “TEACHER'S LEADERSHIP TEACHING 
creating models of learning skills to continue to learn even during a pandemic. One of the strategies often referred to by experts is the blended learning strategy in the school environment when the school reopens later. ${ }^{5}$

When education was still hit by a pandemic, with the policy of distance learning, education stockholders agreed that teaching was a little more specific with the strategy of presenting lectures for each learning path, giving enough time for student performances, discussions, and reflection on assignments, which sometimes schools have limited services compared to other schools last year's system then all to adjust to the demands of distance learning. ${ }^{6}$ For more than a year, however, the learning environment must have a wellstructured blended strategy. So, schools will integrate these methods in measurable units, adequate equipment, clear goals, and a new, directed cycle. ${ }^{7}$ The learning of blended learning strategies has existed for a long time but is not very well known in the context of education in Indonesia even though this strategy is perfect and is a combination of face-to-face learning; traditional strategies, and part of online learning while students are in the schoolroom with the teacher. ${ }^{8}$

When viewed from the point of view, the blended learning method provides students with a face-to-face and online learning experience with the help of adequate technology. Blended learning should also incorporate student guidance techniques on how to use technological media such as live supervision or chat, group dialogue methods, and small group collaboration with technology so that it is easy to provide virtual classroom learning that students can do while they are at home if they have access to technology. This is very important when schools are already at the stage of blended learning. ${ }^{9}$ When it comes to Learning Management Systems or LMS, they should be utilized to provide regular and scalable virtual and online teaching. This learning management system (LMS) enables teachers to maintain a database of all assignments and exercises that students may complete to finish all assignments and major courses successfully.

The efforts of teachers to find a learning management system that can support blended learning do require expert control and assistance. ${ }^{10}$ Because expert-assisted conversation and learning will add unique information where the unique features of blended

STRATEGY SUPPORTING STUDENT LEARNING DURING THE COVID-19 DISRUPTION,” Nidhomul Haq: Jurnal Manajemen Pendidikan Islam 5, no. 3 (21 November 2020): 321-33, https://doi.org/10.31538/ndh.v5i3.984. SUDARMO dkk., "The Identification of Online Strategy Learning Results While Students Learn from Home During the Disruption of the COVID-19 Pandemic in Indonesia," Journal of Contemporary Issues in Business and Government 27, no. 2 (8 Maret 2021): 1950-56, https://doi.org/10.47750/cibg.2021.27.02.205.

5 Rebecca Francis dan Susan J. Shannon, "Engaging with blended learning to improve students' learning outcomes," European Journal of Engineering Education 38, no. 4 (2013): 359-69.

${ }^{6}$ Ghada Refaat El Said, "How Did the COVID-19 Pandemic Affect Higher Education Learning Experience? An Empirical Investigation of Learners' Academic Performance at a University in a Developing Country," Advances in Human-Computer Interaction 2021 (2021).

${ }^{7}$ Beverly Park Woolf, Building intelligent interactive tutors: Student-centered strategies for revolutionizing e-learning (Morgan Kaufmann, 2010).

${ }^{8}$ Henny Yulia, "Online learning to prevent the spread of pandemic corona virus in Indonesia," ETERN $A L$ (English Teaching Journal) 11, no. 1 (2020).

${ }^{9}$ Bonk dan Graham, The handbook of blended learning.

10 Ali Alammary, Judy Sheard, dan Angela Carbone, "Blended learning in higher education: Three different design approaches," Australasian Journal of Educational Technology 30, no. 4 (2014). 
learning-based learning, a mixture of the internet and face-to-face, are very in line with learning strategy guidelines affected by the pandemic crisis. ${ }^{11}$ If the conversation of the entire technology-mixed learning session is under expert guidance, teachers will be more confident about the results. Likewise, the collection of minimal assignments is at the core of the blended learning guide for blended learning. Blended learning spaces allow students to be more independent and personalized to share opinions and learn with other friends through virtual meetings, where the achievements that started in class can continue well after the session is over. $^{12}$ Teachers who have never taught virtual-based students, have never interacted with a learning management system (LMS), and may have never applied digital technology in the classroom need to be demonstrated how to use an LMS and transfer knowledge on a nondigital or straightforward basis on assignments, exercises, laboratories. Applications and need to follow up quickly and effectively. ${ }^{13}$

They refer to Core 4 of distance learning as one of the main focus areas for teachers of online learning-related training and along these lines of mixed awareness. ${ }^{14}$ School districts, or at least individual schools, must agree on the framework to provide web-based learning. First and foremost, schools must choose which learning management system (LMS) they will use so that all students, regardless of grade level or teacher, use the same system. Many schools that use Google Education tools generally use Google Classroom. Second, schools must choose what methods teachers and students will use to store and share notes. ${ }^{15}$ For example, Google Education schools use Google Drive. With Core 4, the teacher can provide students with a web-based learning experience while in class, and if or when schools need to close and move entirely online, the students will be ready because they have learned how to use the digital tools they need to learn. At home! All students will approach this learning paradigm as schools and instructors are forced to integrate learning innovations and do mixed learning as we will have students telecommuting. ${ }^{16}$

How can instructors in study rooms complete with lively music, realistic images, striking recordings, and friends who like to share knowledge from the palm of students' hands?. How are teachers going to equip and bring all of these items to the homeroom? Coupled with the obstacles that high school students are delayed on their way to graduation, as well as evidence that most of them have participated in free social interactions. ${ }^{17}$ For our program, blended learning consists of a combination of advanced realizations, which can be accessed 24 hours a day, seven days a week from anywhere the student has an internet

11 Catherine Attard dan Kathryn Holmes, "An exploration of teacher and student perceptions of blended learning in four secondary mathematics classrooms," Mathematics Education Research Journal, 2020, 1-22.

12 Feifei Han Han dkk., "Personalised learning networks in the university blended learning context," Comunicar. Media Education Research Journal 28, no. 1 (2020).

13 Shilpi Kumari, "Personalised, flexible and blended learning features of moodle-LMS," Educational Quest-An International Journal of Education and Applied Social Sciences 7, no. 1 (2016): 53-56.

${ }^{14}$ John Watson, "Blended Learning: The Convergence of Online and Face-to-Face Education. Promising Practices in Online Learning.," North American Council for Online Learning, 2008.

15 Thomas J. Kane dkk., "Evaluating teacher effectiveness: Can classroom observations identify practices that raise achievement?," Education Next 11, no. 3 (2011): 54-61.

${ }^{16}$ Nina Bergdahl dan Jalal Nouri, "Covid-19 and crisis-prompted distance education in Sweden," Technology, Knowledge and Learning 26, no. 3 (2021): 443-59.

17 Stephen Wade, The beautiful music all around us: field recordings and the American experience (University of Illinois Press, 2012). 
connection; one-on-one instruction with a qualified educator; and task-based regional administration learning activities. ${ }^{18}$ Students are evaluated on their mix of course completion through a computerized learning framework and instructor-provided drawings illustrating ideas applied to locally-based activities. Students are attracted to this method because it allows students to work at their own pace while having instructors help them in areas where they need help and give back to the local community. ${ }^{19}$

When all this is combined with a committed staff, which ensures that students see their way through high school and beyond, there is no reason for students to be left out. ${ }^{20} \mathrm{We}$ have created a framework for educational planning based on the five components that form the basis of our blended learning methods. The most liberating feature of this approach is that teachers are allowed to tackle problems and be as creative as they want to be. Students will continue to use their e-learning software but will be provided with live meetings and instructor visual recordings that students can use if they cannot attend live sessions and need further assistance. It is impossible to reintroduce students to school using recommended pacing guides or instructor handbooks. ${ }^{21}$ Did the teacher mention that flexibility is what this framework needs? Each new class of children will have its own unique set of needs and interests. Each instructor will be given virtual time to respond to questions from students and provide comments on assignments. Individuals from the local community will be encouraged to join virtual sessions with students to assist their venture-based learning activities. This framework must be adaptable to be student-centered, socially aware, and tailored to the individual preferences of students. ${ }^{22}$

\section{METHOD}

In order for us to be able to answer the problem of the study of blended learning strategies to improve learning outcomes in the future when the school has entered the reopening school phase, we have passed a series of data searches through electronic channels in many technology-based educational, scientific journals in an era disrupted by the pandemic crisis. To get the correct data for the needs of educational data related to study technology, we specifically search for data on publications such as Google Books, Elsevier, Sagepub, Taylor \& France, and ERIC. ${ }^{23}$ Furthermore, a review effort involves a strict evaluation and coding system to understand it with accuracy to draw valid conclusions and answer the core of the problem. Because we carried out this study during the PPKM implementation of restrictions on public movement, we decided that this study would only rely on secondary data, and we

\footnotetext{
18 Ratikorn Sirisatit, "An activity theory perspective on task-based instruction in a university business EFL class in Thailand: A sociocultural case study" (PhD Thesis, University of Pittsburgh, 2010).

${ }^{19}$ Dana L. Thomson, 'Beyond the classroom walls: Teachers' and students' perspectives on how online learning can meet the needs of gifted students," Journal of Advanced Academics 21, no. 4 (2010): 662-712.

20 Thomas J. Sergiovanni, Strengthening the heartbeat: Leading and learning together in schools (John Wiley \& Sons, 2015).

21 Clayton D. Brown, "Proven Strategies for Blended Learning: Case Studies from Distance Teaching in History," dalam Interdisciplinary Approaches to Distance Teaching (Routledge, 2015), 87-103.

22 Thomas Gatzemann, Karin Schweizer, dan Albrecht Hummel, "EFFECTIVENESS OF SPORTS ACTIVITIES WITH AN ORIENTATION ON EXPERIENTIAL EDUCATION, ADVENTURE-BASED LEARNING AND OUTDOOR-EDUCATION.," Kinesiology 40, no. 2 (2008).

23 Margaret R. Roller dan Paul J. Lavrakas, Applied qualitative research design: A total quality framework approach (Guilford Publications, 2015).
} 
designed the report in qualitative exploitative data in depth. For this reason, we follow several scientific writers under a descriptive qualitative design review study. ${ }^{24}$

\section{RESULTS AND DISCUSSION}

\section{Peer-review learning and blended learning strategy}

We found thirty articles on the effectiveness of blended learning that per-review has two-thirds of cases of students who had made blended learning systems a partner in higher education in the United States and the United Kingdom. Through semi-experiments before and after the study, it was found that blended learning and peer teaching categories helped students to gain new learning outcomes and abilities. ${ }^{25}$ Still, on the subject of understanding the efficiency of blended learning, small group discussions or collaborative and cooperative learning in university programs have also improved student learning outcomes to develop the quality of graduates. Likewise, when schools reopen, face-to-face lectures are essential for graduate students.

However, when the world of education is still in the grip of a pandemic, blended learning that combines traditional classroom methods with online education is one solution. Graduates studying information systems were selected for this pilot project after a survey was conducted at the end of the semester to evaluate this mixed learning approach. ${ }^{26}$ The core findings of the three reviews above prove that blended learning is very appropriate to be applied, especially if education is still in a pandemic atmosphere where the open system learning system is still limited. The blended learning system allows two models of learning interactions to occur. Ideally, some things cannot be solved with the help of online learning, so it should ideally be done face-to-face, which brings a health prototype. ${ }^{27}$

\section{Project-based education in blended learning}

Jin Rong Yang ${ }^{28}$ utilized undertaking-based web-based learning to explore the impact of mixed and task put together learning concerning the imagination considering preservice science educators during the Covid-19 pandemic. They looked to decide the impact of Blended Learning (BL) and Project-Based Learning (PBL) on preservice instructors' imaginative reasoning while at the same time concentrating on science. Seventy-six science instruction understudies were enrolled as examination members in a semi-trial setting. The average worth of innovative thinking in the exploratory class is 91 , with an $\mathrm{N}$-acquire file of 0.62 , fundamentally more than the worth in the control class (76). As per their understanding of their outcomes, mixed learning and venture-based adapting generously influence the

\footnotetext{
${ }^{24}$ Joseph A. Maxwell, Qualitative research design: An interactive approach (Sage publications, 2012).

${ }_{25}$ Martin Stigmar, "Peer-to-peer teaching in higher education: A critical literature review," Mentoring \& Tutoring: partnership in learning 24, no. 2 (2016): 124-36.

${ }^{26}$ Elsie SK Chan, "An innovative learning approach: Integrate peer-to-peer learning into blended learning," International journal of global education 1, no. 1 (2012).

${ }^{27}$ Reza Rachmadtullah dkk., "Use of blended learning with moodle: Study effectiveness in elementary school teacher education students during the COVID-19 pandemic," International journal of advanced science and technology 29, no. 7 (2020): 3272-77.

${ }^{28}$ Jin Rong Yang, Fabian Hadipriono Tan, dan Adrian Hadipriono Tan, “The application of multimedia system for ancient construction in civil engineering courses," dalam Pedagogies of Digital Learning in Higher Education (Routledge, 2020), 183-97.
} 
imaginative considering abilities of preservice science teachers. BL and PBL are significantly more effective than standard methodologies in fostering the inventive considering abilities of preservice science educators. While concentrating on science, science instructors help understudies in fostering their capacity to think imaginatively. Therefore, we believe that utilizing a mixed learning approach during the school's return is probably the ideal alternative.

This exploration is the same as Saboowala and Manghirmalani's, ${ }^{29}$ which concentrates on "Status of preservice instructors for mixed learning as a method of guidance in the postCOVID-19 time." Hsieh et al. ${ }^{30}$ are among the individuals who added to this review. A contextual investigation of a bundle plan course for professional secondary school understudies fuses blended learning and innovative task-based learning and a trial of greatness and understudy fulfillment with a wrap plan course that consolidates both blended learning and inventive undertaking-based learning. Perform research on gift-wrapping configuration preparing; 44 understudies from the Promotion and Design course were partitioned into 11 groups. Blended techniques training joins regular homeroom guidance with an understudymade internet learning stage for discussing and sharing thoughts and assets.

\section{Technological integration is a part of blended learning.}

The findings of Bosch et al. ${ }^{31}$ revealed consequences for students' intrinsic motivation if blended learning which includes cooperative learning, is included in the integrated blended learning design paradigm. Cooperative learning (CL) in face-to-face classrooms has received much attention in recent months. A study described in this article will result in complete blended learning (BL) design paradigm, detailed in the following article. According to the qualitative data, students' intrinsic motivation (IM) increased due to implementing the CLBL module design. A mixed learning environment for applied mathematics topics was created by Karma et al. ${ }^{32}$ using instructional methods and technology integration. Students can use mathematics that determines their potential for success in the Mechanical Engineering Department. For the application of mechanical engineering to be successful, students must solve mathematical engineering problems. Because it is difficult for most students to understand, integrated learning can be an effective teaching method.

Explanation of ideas, problem-based learning, and problem-solving are just some of the learning methods used. Likewise, the study of Shih, ${ }^{33}$ wants to understand the role of Web

\footnotetext{
29 Rabiya Saboowala dan Pooja Manghirmalani Mishra, "Readiness of in-service teachers toward a blended learning approach as a learning pedagogy in the post-COVID-19 Era," Journal of Educational Technology Systems 50, no. 1 (2021): 9-23.

${ }^{30}$ Hua-Yun Hsieh, Shi-Jer Lou, dan Ru-Chu Shih, "Applying blended learning with creative project-based learning: A case study of wrapping design course for vocational high school students," TOJS AT 3, no. 2 (2013): $18-27$.

${ }^{31}$ Chantelle Bosch, Elsa Mentz, dan Gerda Marie Reitsma, "Integrating cooperative learning into the combined blended learning design model: implications for students' intrinsic motivation," International Journal of Mobile and Blended Learning (IJMBL) 11, no. 1 (2019): 58-73.

${ }^{32}$ I. Karma, I. Ketut Darma, dan I. Santiana, "Teaching strategies and technology integration in developing blended learning of applied mathematics subject," International research journal of engineering, IT \& scientific research, 2019.

33 Ru-Chu Shih, "Can Web 2.0 technology assist college students in learning English writing? Integrating Facebook and peer assessment with blended learning," Australasian Journal of Educational Technology 27, no. 5 (2011).
} 
2.0 technology in developing students' ability to write in English? Social media and peer review are two components of blended learning. Using Facebook and peer evaluation in conjunction with teaching college English writing classes, this study investigates its impact on student performance. The participants in this study were twenty-three first-year English majors at a Taiwan technical institute. A study conducted by researchers found that utilizing Facebook for peer evaluation while learning to write English may be both fun and rewarding. Using these findings, ESL English writing course instructors may develop more effective teaching methods. ${ }^{34}$ Based on free and open-source software, Moodle is a collaboratively blended learning environment. Several studies have shown that cooperative learning has the potential to improve student performance in high school physics. With platform modules that can be modified to meet specific user needs, Moodle is a free, easy-to-use, open-source learning management system. Class XII high school students, will participate in this study to investigate how blended-cooperative learning affects their understanding of physics.

\section{A teacher is in charge of instruction in a blended way.}

Jeffrey et al. ${ }^{35}$ examine how school instructors in mixed learning can balance the online and classroom components? If instructors are not encouraged to rethink and reorganize their courses to provide students with more opportunities and diverse learning experiences, blended learning will fall short of its promise of better learning. Only one study examined blended learning, and it made recommendations on how institutions and instructors could maximize the benefits of this method. Stallings \& Oliver, ${ }^{36}$ also prove how educators' approaches are preparing for the growing popularity of diverse learning settings. For more than two decades, higher education has incorporated diverse learning settings. K-12 public and private schools have started experimenting with blended learning in recent years. This study states that practical mixed education teacher training should have three components: contextual, instructional, and technical. Each of these components is interwoven with wellknown instructional design methods.

Continuation of the teacher is in charge of instruction, Lockee, ${ }^{37}$ says that due to the shift in digital technology, there is also a shift in context. Then the teaching system of teachers should consider their professional development in the COVID-19 era for online and blended teaching. This article responds to the publication "Improving teacher professional development for online and hybrid learning." The real downside of the worldview utilized in this review is that the TPD for current OBL necessities might shift as educators work in exceptionally assorted learning and execution conditions. The discoveries of this review can be applied to the quick reception of computerized instructing and learning after the COVID-

\footnotetext{
${ }^{34}$ Dwi Sulisworo, Sri Puji Agustin, dan Endang Sudarmiyati, "Cooperative-blended learning using Moodle as an open source learning platform,” International Journal of Technology Enhanced Learning 8, no. 2 (2016): 187-98.

${ }_{35}$ Lynn M. Jeffrey dkk., "Blended learning: How teachers balance the blend of online and classroom components.," Journal of Information Technology Education 13 (2014).

${ }^{36}$ Kevin Oliver dan Dallas Stallings, "Preparing teachers for emerging blended learning environments," Journal of Technology and Teacher Education 22, no. 1 (2014): 57-81.

37 Barbara B. Lockee, "Shifting digital, shifting context:(re) considering teacher professional development for online and blended learning in the COVID-19 era," Educational Technology Research and Development 69, no. 1 (2021): $17-20$.
} 
19 pandemic. Accordingly, instructor education can be joined in two ways; online innovation and vis-à-vis as formal occasions. ${ }^{38}$

\section{Virtual learning stage in mixed learning}

McCutcheon, ${ }^{39}$ examined the pre-enrolment nursing understudy program to comprehend the distinction between online versus mixed mastering with clinical supervisee abilities. This review follows the bearing of the World Health Organization, where schooling should get clinical oversight during their investigations. In this way, to comprehend whether the party picks the eye to eye or online talk framework. These two methodologies ought to be remembered for well-being professional training as essential for working on tolerant security and care. Scientists perceive that the use of web-based learning methods and mixed learning in advanced education is expanding and that an exhaustive investigation of these methodologies will further develop information on the best way to show clinical management.

Consequently, to work on the prior year experience of plan understudies at the University of Adelaide utilizing the mix of virtual and actual learning settings, a sort of examination finding should be found before the course starts. Through one semester, 120 plan understudies, including 27 worldwide understudies, were conveyed through a Facebookfacilitated online gathering. This review analyzes understudies who are "advanced locals" and web-based media use in advanced education to work with learning and instructing. ${ }^{40}$

Similar support over virtual learning issues in developing learning, Joy Connoly, ${ }^{41}$ studied the blended learning method using the frog vile platform to increase student success in teaching games for understanding. Supported by a study in Malaysia, instructors in Malaysian secondary schools use a mixed learning strategy based on the Frog Virtual Learning Environment (VLE) platform. Because there must be efforts to increase the use of Frog VLE in schools and research to determine the effect of blended learning on children's handball performance, then it was found that the students improved their performance and learning outcomes in terms of strategy and tactical knowledge when it came to overcoming the challenges of the game.

\section{Development of essential skills in blended learning}

For most of the world's population, where computers and the Internet are easily accessible and cheap, blended learning is the educational norm. Self-study is supplemented with required one-on-one time with the teacher. This research examines how Thai English for Special Purposes (ESP) students learn. According to results, online education improves the four language acquisition skills and student motivation. ${ }^{42}$ Likewise, through a randomized

\footnotetext{
38 Allison Powell, Beth Rabbitt, dan Kathryn Kennedy, "iNACOL Blended Learning Teacher Competency Framework.," International Association for K-12 Online Learning, 2014.

${ }^{39}$ Karen McCutcheon, Peter O’Halloran, dan Maria Lohan, "Online learning versus blended learning of clinical supervisee skills with pre-registration nursing students: a randomised controlled trial," International Journal of Nursing Studies 82 (2018): 30-39.

40 Joshua McCarthy, "Blended learning environments: Using social networking sites to enhance the first year experience," Australasian Journal of Educational Technology 26, no. 6 (2010).

${ }^{41}$ Joy Connolly, Vile eloquence: Performance and identity in Greco-Roman rhetoric (University of Pennsylvania, 1997).

${ }^{42}$ Choosri Banditvilai, "Enhancing students language skills through blended learning," Electronic Journal of eLearning 14, no. 3 (2016): pp223-232.
} 
controlled trial, the study of Stewart et al. ${ }^{43}$ was conducted to study how to improve the evaluation ability of clinical students in infants. A blended learning approach improves clinical student infant assessment skills and increases their satisfaction with infant assessment. Undergraduate clinical students in tertiary education clinics were randomly assigned to a regular neonatology preparation program (control group) or internet-based supplementary admission to the PENSKE Infant Examination Learning Module (mixed learning group). Compared with the benchmark group, the mixed study group had a significantly higher mean newborn evaluation score.

The findings of Iryna, ${ }^{44}$ are a group of people who work together to start something. Examination of the literature on using mixed learning methods to help healthcare professionals improve their relationship skills. Mixed learning combines the advantages of face-to-face and online learning with the help of socialization objectives and practical activities. The development of relationship skills appears to be an afterthought in many studies but is essential for the proper acquisition and use of clinical talent served by hybrid courses. Sulistyo, ${ }^{45}$ assessed that students' scholastic writing skills were improved after using mixed learning with Facebook. This study aims to see how effective blended, flexible learning using Facebook improves students' writing skills. Thoughts, associations, phrases, and feelings are all used as criteria to determine writing ability. The findings show that this learning method has produced good results in several areas, primarily focusing on forming and sorting ideas into a structured framework.

\section{Global Link in blended learning}

Bonk and Spring, ${ }^{46}$ investigated seven distinct domains, including mixed learning and distribution networks references. More grounded communication and cooperation, it is believed, would benefit the worldwide blended learning (BL) community. Coordinated efforts are presently limited, and the region's frame of reference is undergoing significant change. After all, BL is expanding worldwide, and each area contributes significantly to the local community. The purpose of this study is to ascertain the locations of the most compelling discussions about BL and, if any, their relation to one another in terms of reference and dissemination. To provide a comprehensive picture of impact and deployment on the ground, we provide the most often cited BL excerpts from each site, the diaries that propagated these pieces, and the referral and distribution methods for each.

Dridi et al, ${ }^{47}$ investigate the difficulties associated with blended learning in refugee camps, concluding that the personal connection prevails when the Internet connection breaks. They concentrate on delivering a global history seminar as part of an extensive open Internet-

\footnotetext{
${ }^{43}$ Vivien Stewart, A world-class education: Learning from international models of excellence and innovation (ASCD, 2012).

${ }^{44}$ Maksymchuk Iryna dkk., "Developing pedagogical mastery of future physical education teachers in higher education institutions," 2018.

45 Wahyu Djoko Sulistyo, "Learning Activities from Learning Resources: Pemanfaatan dan Pemaknaan Situs Sejarah Kawasan Alun-Alun Merdeka Kota Malang Pemanfaatan dan Pemaknaan Situs Sejarah Kawasan AlunAlun Merdeka Kota Malang," Jurnal Pendidikan Sejarab Indonesia 2, no. 1 (2019): 49-63.

${ }^{46}$ Bonk dan Graham, The handbook of blended learning.

47 Mohamed Aziz Dridi dkk., "Challenges of Blended Learning in Refugee Camps: When Internet Connectivity Fails, Human Connection Succeeds," The International Review of Research in Open and Distributed Learning 21, no. 3 (2020): 250-63.
} 
based course and on the learning challenges students encounter in three emergencies: the Azraq refugee camp, the Kakuma internment camp, and the metropolitan community exiles in Amman. Educators are having difficulties evaluating their kids' needs and concerns due to the continuing Internet availability issue. The study's premise is that learning at the camp cannot be done correctly without internet access. This implies they can still establish human-tohuman contact. Thus, both methods (blended learning) must be used for success. ${ }^{48}$

Hilliard, ${ }^{49}$ reviews professional progress training and the contribution of general homeroom teachers to different instructive initiatives across disciplines in a global network of proven, blended learning. Associations that are more skilled in preparing developments, programs in divisions, and units in colleges and universities are introducing blended learning as another educational tool for use in educational administration delivery and administration due to financial and time constraints. With the help of mixed learning innovations, the preparatory steps for administrative progress take place following the interest in eye movements. This evaluation will look at the definition of guidelines for blended learning, as well as advantages, group support, strategies, board issues, justification for extension, sharp turn of events, purchases, subsidies, assessments, and future focal points and recommendations. ${ }^{50}$

\section{CONCLUSION}

We believe that the purpose of this study has been achieved where we want to gain a comprehensive understanding of how the blended learning strategy can improve learning outcomes during the reopening of school. Without a review of the evidence from previous studies, we may not be able to answer the purpose of this study. So, we reviewed dozens of findings in scientific journals such as ERIC, Sagepub, Taylor \& France, Google Books, and other publications. The results include a blended learning strategy in which can be described in several strategies. For example, peer-reviewed strategies, project-based learning, technological education, classroom teacher teaching, platform learning tools, development of learning skills, and global links were all supportive data. Hopefully, these findings become valid data and literature for academic work, research data, and field applications in schools and universities.

\section{ACKNOWLEDGMENT}

The authors are grateful for all the help and support that made this study a success. We are very grateful, and hopefully, the results can be helpful.

\section{REFERENCE}

\footnotetext{
48 Ruth Boelens, Bram De Wever, dan Michiel Voet, "Four key challenges to the design of blended learning: A systematic literature review," Educational Research Review 22 (2017): 1-18.

49 Ann Toler Hilliard, "Global Blended Learning Practices for Teaching and Learning, Leadership and Professional Development.," Journal of International Education Research 11, no. 3 (2015): 179-88.

${ }^{50}$ Brenda DuBois dan Karla Krogsrud Miley, “An Empowering Profession,” 2019.
} 
Alammary, Ali, Judy Sheard, dan Angela Carbone. "Blended learning in higher education: Three different design approaches." Australasian Journal of Educational Technology 30, no. 4 (2014).

Aslan, Aslan. HIDDEN CURRICULUM. Pena Indis, 2019. . "MAKNA KURIKULUM TERHADAP TEORI TENTANG BELAJAR PADA PERUBAHAN PERILAKU ANAK DIDIK." Cross-Border: Jurnal Kajian Perbatasan Antarnegara, Diplomasi Dan Hubungan Internasional 1, no. 2 (2018): 56-65.

Aslan, Aslan, Silvia Silvia, Budi Sulistiyo Nugroho, M. Ramli, dan Rusiadi Rusiadi. “TEACHER'S LEADERSHIP TEACHING STRATEGY SUPPORTING STUDENT LEARNING DURING THE COVID-19 DISRUPTION." Nidhomul Haq: Jurnal Manajemen Pendidikan Islam 5, no. 3 (21 November 2020): 321-33. https://doi.org/10.31538/ndh.v5i3.984.

Aslan, Aslan, dan Suhari Suhari. "Sejarah Kurikulum Pendidikan Islam di Brunei Darussalam." Jurnal Iqra': Kajian Ilmu Pendidikan 4, no. 1 (2019): 113-27.

Attard, Catherine, dan Kathryn Holmes. "An exploration of teacher and student perceptions of blended learning in four secondary mathematics classrooms." Mathematics Education Research Journal, 2020, 1-22.

Aziz, Azmahani A., Khairiyah M. Yusof, dan Jamaludin M. Yatim. "Evaluation on the effectiveness of learning outcomes from students' perspectives." Procedia-Social and Behavioral Sciences 56 (2012): 22-30.

Banditvilai, Choosri. "Enhancing students language skills through blended learning." Electronic Journal of e-Learning 14, no. 3 (2016): pp223-232.

Bergdahl, Nina, dan Jalal Nouri. "Covid-19 and crisis-prompted distance education in Sweden." Technology, Knowledge and Learning 26, no. 3 (2021): 443-59.

Boelens, Ruth, Bram De Wever, dan Michiel Voet. "Four key challenges to the design of blended learning: A systematic literature review." Educational Research Review 22 (2017): $1-18$.

Bonk, Curtis J., dan Charles R. Graham. The handbook of blended learning: Global perspectives, local designs. John Wiley \& Sons, 2012.

Bosch, Chantelle, Elsa Mentz, dan Gerda Marie Reitsma. "Integrating cooperative learning into the combined blended learning design model: implications for students' intrinsic motivation." International Journal of Mobile and Blended Learning (IJMBL) 11, no. 1 (2019): $58-73$.

Brown, Clayton D. "Proven Strategies for Blended Learning: Case Studies from Distance Teaching in History." Dalam Interdisciplinary Approaches to Distance Teaching, 87-103. Routledge, 2015.

Chan, Elsie SK. "An innovative learning approach: Integrate peer-to-peer learning into blended learning." International journal of global education 1, no. 1 (2012).

Connolly, Joy. Vile eloquence: Performance and identity in Greco-Roman rhetoric. University of Pennsylvania, 1997.

Cronje, Johannes. "Towards a new definition of blended learning." Electronic journal of eLearning 18, no. 2 (2020): pp114-121.

Dridi, Mohamed Aziz, Dhinesh Radhakrishnan, Barbara Moser-Mercer, dan Jennifer DeBoer. "Challenges of Blended Learning in Refugee Camps: When Internet Connectivity Fails, Human Connection Succeeds." The International Review of Research in Open and Distributed Learning 21, no. 3 (2020): 250-63.

DuBois, Brenda, dan Karla Krogsrud Miley. "An Empowering Profession,” 2019.

El Said, Ghada Refaat. "How Did the COVID-19 Pandemic Affect Higher Education Learning Experience? An Empirical Investigation of Learners' Academic Performance 
at a University in a Developing Country." Advances in Human-Computer Interaction 2021 (2021).

Fethullah, Gulen. "Education from cradle to grave - Fethullah Gülen's Official Web Site." Diakses 28 Mei 2019. https://fgulen.com/en/fethullah-gulens-works/toward-aglobal-civilization-of-love-and-tolerance/education/25271-education-from-cradle-tograve.

Fifi, Nofiaturrahmah. "Model Pendidikan Karakter di Pesantren (Studi Pondok Pesantren AlMunawwir Krapyak dan Muallimin Muallimat Yogyakarta." Doctoral, UIN Sunan Kalijaga, 2015. http://digilib.uin-suka.ac.id/23812/.

Fitri, S., dan C. L. Zahari. "The implementation of blended learning to improve understanding of mathematics." Dalam Journal of Physics: Conference Series, 1188:012109. IOP Publishing, 2019.

Francis, Rebecca, dan Susan J. Shannon. "Engaging with blended learning to improve students' learning outcomes." European Journal of Engineering Education 38, no. 4 (2013): 359-69.

Gatzemann, Thomas, Karin Schweizer, dan Albrecht Hummel. "EFFECTIVENESS OF SPORTS ACTIVITIES WITH AN ORIENTATION ON EXPERIENTIAL EDUCATION, ADVENTURE-BASED LEARNING AND OUTDOOREDUCATION." Kinesiology 40, no. 2 (2008).

Han, Feifei Han, Robert Ellis Ellis, Feifei Han, dan Robert Ellis. "Personalised learning networks in the university blended learning context." Comunicar. Media Education Research Journal 28, no. 1 (2020).

Hilliard, Ann Toler. "Global Blended Learning Practices for Teaching and Learning, Leadership and Professional Development." Journal of International Education Research 11, no. 3 (2015): 179-88.

Hsieh, Hua-Yun, Shi-Jer Lou, dan Ru-Chu Shih. "Applying blended learning with creative project-based learning: A case study of wrapping design course for vocational high school students." TOJSAT 3, no. 2 (2013): 18-27.

Iryna, Maksymchuk, Maksymchuk Borys, Frutziuk Valentina, Matyiichuk Tetiana, Demchenko Iryna, Babii Inna, Tsymbal-Slatvinska Svitlana, Nikitenko Alona, Bilan Valentyna, dan Sitovskyi Andrii. "Developing pedagogical mastery of future physical education teachers in higher education institutions," 2018.

Jeffrey, Lynn M., John Milne, Gordon Suddaby, dan Andrew Higgins. "Blended learning: How teachers balance the blend of online and classroom components." Journal of Information Technology Education 13 (2014).

Kane, Thomas J., Eric S. Taylor, John H. Tyler, dan Amy L. Wooten. "Evaluating teacher effectiveness: Can classroom observations identify practices that raise achievement?" Education Next 11, no. 3 (2011): 54-61.

Karma, I., I. Ketut Darma, dan I. Santiana. "Teaching strategies and technology integration in developing blended learning of applied mathematics subject." International research journal of engineering, IT \& scientific research, 2019.

Kumari, Shilpi. "Personalised, flexible and blended learning features of moodle-LMS." Educational Quest-An International Journal of Education and Applied Social Sciences 7, no. 1 (2016): 53-56.

Lickona, Thomas. Educating for Character: How Our Schools Can Teach Respect and Responsibility. New York: Bantam Books, 2009.

Lockee, Barbara B. "Shifting digital, shifting context:(re) considering teacher professional development for online and blended learning in the COVID-19 era." Educational Technology Research and Development 69, no. 1 (2021): 17-20. 
Ma`arif, Muhammad Anas, dan Ari Kartiko. "Fenomenologi Hukuman di Pesantren : Analisis Tata Tertib Santri Pondok Pesantren Daruttaqwa Gresik.” Nadwa 12, no. 1 (22 Juni 2018): 181-96. https://doi.org/10.21580/nw.2018.12.1.1862.

Manullang, Sardjana Orba, Mardani Mardani, dan Aslan Aslan. "The Effectiveness of AlQuran Memorization Methods for Millennials Santri During Covid-19 in Indonesia." Ną̧hruna: Jurnal Pendidikan Islam 4, no. 2 (12 Juni 2021): 195-207. https://doi.org/10.31538/nzh.v4i2.1334.

Maxwell, Joseph A. Qualitative research design: An interactive approach. Sage publications, 2012.

McCarthy, Joshua. "Blended learning environments: Using social networking sites to enhance the first year experience." Australasian Journal of Educational Technology 26, no. 6 (2010).

McCutcheon, Karen, Peter O'Halloran, dan Maria Lohan. "Online learning versus blended learning of clinical supervisee skills with pre-registration nursing students: a randomised controlled trial.” International Journal of Nursing Studies 82 (2018): 30-39.

Oliver, Kevin, dan Dallas Stallings. "Preparing teachers for emerging blended learning environments." Journal of Technology and Teacher Education 22, no. 1 (2014): 57-81.

Powell, Allison, Beth Rabbitt, dan Kathryn Kennedy. "iNACOL Blended Learning Teacher Competency Framework.” International Association for K-12 Online Learning, 2014.

Putra, Purniadi, Fahrina Yustiasari Liriwati, Tasdin Tahrim, Syafrudin Syafrudin, dan Aslan Aslan. "The Students Learning from Home Experiences during Covid-19 School Closures Policy In Indonesia." Jurnal Iqra': Kajian Ilmu Pendidikan 5, no. 2 (5 September 2020): 30-42. https://doi.org/10.25217/ji.v5i2.1019.

Rachmadtullah, Reza, Rasmitadila Marianus Subandowo, Megan Asri Humaira, Rusi Rusmiati Aliyyah, Achmad Samsudin, dan Muhammad Nurtanto. "Use of blended learning with moodle: Study effectiveness in elementary school teacher education students during the COVID-19 pandemic." International journal of advanced science and technology 29, no. 7 (2020): 3272-77.

Roller, Margaret R., dan Paul J. Lavrakas. Applied qualitative research design: A total quality framework approach. Guilford Publications, 2015.

Saboowala, Rabiya, dan Pooja Manghirmalani Mishra. "Readiness of in-service teachers toward a blended learning approach as a learning pedagogy in the post-COVID-19 Era." Journal of Educational Technology Systems 50, no. 1 (2021): 9-23.

Sergiovanni, Thomas J. Strengthening the heartbeat: Leading and learning together in schools. John Wiley \& Sons, 2015.

Shih, Ru-Chu. "Can Web 2.0 technology assist college students in learning English writing? Integrating Facebook and peer assessment with blended learning." Australasian Journal of Educational Technology 27, no. 5 (2011).

Sirisatit, Ratikorn. "An activity theory perspective on task-based instruction in a university business EFL class in Thailand: A sociocultural case study." PhD Thesis, University of Pittsburgh, 2010.

Stewart, Vivien. A world-class education: Learning from international models of excellence and innovation. ASCD, 2012.

Stigmar, Martin. "Peer-to-peer teaching in higher education: A critical literature review." Mentoring \& Tutoring: partnership in learning 24, no. 2 (2016): 124-36.

SUDARMO, Mulyawan Safwandy Nugraha, MARDHIAH, Festus Evly R. I.liow, dan ASLAN. "The Identification of Online Strategy Learning Results While Students Learn from Home During the Disruption of the COVID-19 Pandemic in Indonesia." Journal of Contemporary Issues in Business and Government 27, no. 2 (8 Maret 2021): 195056. https://doi.org/10.47750/cibg.2021.27.02.205. 
Sulistyo, Wahyu Djoko. "Learning Activities from Learning Resources: Pemanfaatan dan Pemaknaan Situs Sejarah Kawasan Alun-Alun Merdeka Kota Malang Pemanfaatan dan Pemaknaan Situs Sejarah Kawasan Alun-Alun Merdeka Kota Malang." Jurnal Pendidikan Sejarah Indonesia 2, no. 1 (2019): 49-63.

Sulisworo, Dwi, Sri Puji Agustin, dan Endang Sudarmiyati. "Cooperative-blended learning using Moodle as an open source learning platform." International Journal of Technology Enhanced Learning 8, no. 2 (2016): 187-98.

Thomson, Dana L. 'Beyond the classroom walls: Teachers' and students' perspectives on how online learning can meet the needs of gifted students." Joumal of Advanced Academics 21, no. 4 (2010): 662-712.

Wade, Stephen. The beautiful music all around us: field recordings and the American experience. University of Illinois Press, 2012.

Watson, John. "Blended Learning: The Convergence of Online and Face-to-Face Education. Promising Practices in Online Learning." North American Council for Online Learning, 2008.

Woolf, Beverly Park. Building intelligent interactive tutors: Student-centered strategies for revolutionizing elearning. Morgan Kaufmann, 2010.

Yang, Jin Rong, Fabian Hadipriono Tan, dan Adrian Hadipriono Tan. "The application of multimedia system for ancient construction in civil engineering courses." Dalam Pedagogies of Digital Learning in Higher Education, 183-97. Routledge, 2020.

Yulia, Henny. "Online learning to prevent the spread of pandemic corona virus in Indonesia." ETERNAL (English Teaching Journal) 11, no. 1 (2020). 